\title{
Supporting lifelong learning in public libraries across Europe.
}

Juliet Eve, Margo de Groot and Anne-Marie Schmidt

Correspondence author: Juliet Eve, Senior Lecturer, University of Brighton

Address: CMIS, Watts Building, Lewes Road, Brighton, BN2 4GJ. Tel: +44 (0) 1273

643506; email: j.eve@brighton.ac.uk.

\begin{abstract}
Purpose: This paper presents findings from the European project PuLLS (Public Libraries in the Learning Society), funded by the EU's Socrates programme.

Approach: Describes a piece of action research, outlining the development and implementation of a model for delivering open learning to adult library users.

Findings: Details of the model, and the course developed and offered by partner libraries are described. Results suggest there is a significant role for libraries to play in supporting both ICT skills and wider information literacy learning.

Research implications: Suggests that libraries are beginning to move from a passive access approach to supporting learning to a more active approach in delivering library-generated content themselves.

Practical implications: Sharing of results may be useful for public libraries wishing to develop open learning facilities/develop audiences for lifelong learning.

Keywords: lifelong learning; public libraries; ICT and information literacy skills.

Case study.
\end{abstract}

\section{Introduction}

The PuLLS (Public Libraries in the Learning Society) project was part of the EU's Grundtvig programme (under the broader remit of the Socrates programme), the aim of which is to enhance the European dimension of lifelong learning, and improve the availability and accessibility of learning opportunities for adults. The PuLLS project sought to improve the role public libraries across Europe can play in delivering learning opportunities. The project aimed to improve adults' (particularly disadvantaged adults) information literacy and active citizenship through informal learning by developing the concept of the public library as an open learning centre. One of the key tasks was to develop a European model for open learning in public libraries, which can develop and deliver (e-)courses, and multimedia content which supports and fosters adult learning. Partners involved in the project were: Århus Libraries in Denmark, Helsinki Libraries in Finland, Sutton Libraries and the University of Brighton in the UK, Ljubljana Libraries in Slovenia, Würzburg Librraies in Germany, Barcelona Libraries and MK5060 - full circle projects based in the Netherlands (1). Details of partners, and the materials and documents discussed below can be found at www.pulls.dk.

\section{Context: lifelong learning in Europe}

\section{Definitions}

Lifelong learning has become one of the major policy goals of Western governments over the last few years, and is closely related to a broad range of other social policies such as (ICT) literacy, or digital citizenship, training and reskilling citizens for the 'Information Society', competitiveness, and job creation. Lifelong learning is defined by the European Commission as: 
all learning activity undertaken throughout life, with the aim of improving knowledge, skills and competence, within a personal, civic, social and/or employment-related perspective. (European Commission, 2003a)

The stress falls on the skills and training aspect of learning, as the Commission sees the role of lifelong learning as a key area in facing up to a number of [social and economic] challenges:

The scale of current economic and social change, the rapid transition to a knowledge-based society and demographic pressures resulting from an ageing population in Europe are all challenges which demand a new approach to education and training, within the framework of lifelong learning. (European Commission, 2003a)

This approach is reflected in the policy statements and initiatives established by the Commission and many member states, and is closely allied with wider 'Information Society' developments which focus on lifelong learning, social inclusion and the expansion of ICT facilities and training as the essential strands for exploiting the benefits of the information age for EU citizens.

In the UK, the Campaign for Learning's definition allows for a more expanded idea of learning as engaging with the world around us:

Learning is a process of active engagement with experience. It is what people do when they want to make sense of the world. It may involve an increase in skills, knowledge or understanding, a deepening of values of the capacity to reflect. Effective learning will lead to change, development and a desire to learn more. (Campaign for Learning, n.d)

In Spain, the concept of lifelong learning is legally defined at both the State and Autonomous Community level. The Informe nacional sobre el debate acerca del aprendizaje permanente en España [National report on the debate on lifelong learning in Spain] defines lifelong learning as the act of useful learning carried out continuously with the aim of improving qualifications, expanding knowledge and aptitudes. (Ministerio de Educación, n.d.)

Denmark's Ministry of Education stresses the long-standing tradition of lifelong learning for adults, and the key role CVU (Continuing Vocational Training) plays in this - in line with European policy, the stress here is on training for unskilled workers, but relevant courses are offered for all adults.

\section{European policy developments}

Until the mid-1990s, European educational policy - and resources for projects to support education, such as the Socrates and Leonardo programmes - was focused on formal adult learning via educational institutions. The white paper of 1995, Towards the Learning Society, saw a shift towards supporting informal ways of learning, and was the start of many policy initiatives designed to encourage what has now come to be known as lifelong learning. 1996, indeed, was designated the European Year of Lifelong Learning; the stress on lifelong learning to support economic policies is evidenced by the launch of this initiative in the EU's white paper entitled Growth, Competitiveness, Employment. Much was made of the need for education and training to 'meet the challenges of the twenty-first century', and to skill 
an adaptable workforce in support of the 'information society' or 'knowledge economy'. This trend towards viewing both formal and informal education as a key weapon in the fight to remain economically competitive has become entrenched in European and national governments during the intervening decade. In 2000, the Lisbon Council produced the Memorandum on Lifelong Learning (European Commission, 2000), re-affirming its belief that:

Europe has indisputably moved into the Knowledge Age

and setting out its position that

the move towards lifelong learning must accompany a successful transition to a knowledge -based economy and society (p.3).

The Memorandum sets out six key messages (with related objectives) for creating a lifelong learning strategy:

- New basic skills for all

o guarantee universal and continuing access to learning for gaining and renewing the skills needed for sustained participation in the knowledge society;

\section{- More investment in human resources}

o visibly raise levels of investment in human resources in order to place priority on Europe's most important assets - its people;

- Innovation in teaching and learning

o develop effective teaching and learning methods and contexts for the continuum of lifelong and lifewide learning;

- Valuing learning

o significantly improve the ways in which learning participation and outcomes are understood and appreciated, particularly non-formal and informal learning;

- Rethinking guidance and counselling

o ensure that everyone can easily access good quality information and advice about learning opportunities throughout Europe and throughout their lives;

- Bringing learning closer to home

o provide lifelong learning opportunities as close to learners as possible, in their own communities and supported through ICT-based facilities wherever appropriate. (pp.10-18)

These were followed in 2001 by a set of indicators on lifelong learning, in an attempt to measure progress, and during the following couple of years, five benchmarks for Education and Training were developed - including one on lifelong learning, which suggested that $15 \%$ of the adult working population should be engaged in some kind of learning. In May 2003, this was adopted as a measure, but the target set was $12.5 \%$. Most recently, in October 2006, the Communication, It Is Never Too Late To Learn (European Commission, 2006), stressed the importance of adult learning, recognising that adult participation in lifelong learning varies widely across member 
states, and that the focus of activity remains on training and educating young people. The document proposed an Action Plan on Adult Learning, to be launched in 2007, and aiming to meet five challenges:

1. Lifting the barriers to participation;

2. Ensuring the quality of adult learning;

3. Introducing systems which recognise and validate learning outcomes;

4. Investing in older people and migrants;

5. Measuring progress via reliable data, and appropriate benchmarks and indicators, in order to inform evidence-based policy making.

During this time, the Socrates and Leonardo programmes have been funding a wide range of projects aimed at supporting these policy concerns, and libraries have been part of a number of networking and research initiatives.

\section{Public libraries and lifelong learning}

Public libraries have an established history of supporting individual and informal learners, and so can also be expected to play an important part in the current lifelong learning landscape. As lifelong learning has been adopted as a policy goal, and formalised in EU and national government agendas, so have libraries formalised their roles in supporting learners - both via policy and position statements, and via the nature of how - and with whom - they provide services. Increasingly, public libraries are being drawn in to assist the delivery of strategic policy goals, and many have seized the opportunity to align themselves with government agendas. This can be seen as a way of raising the profile of libraries, and, in the UK, certainly, is increasingly linked to the 'evaluation' culture in which all (local) government services are having to prove their value, and relevance to wider policy agendas. The Museums, Libraries and Archives Council (MLA) - the UK body which provides strategic direction and support for the library, museums and archives sector - has established strategic initiatives around what are termed the 'Shared Priorities' between national and local government (see Local Government Association, 2002; MLA, n.d.). Public libraries are keen to place themselves at the heart of these debates and policy initiatives around lifelong learning, taking back some of the ground they naturally feel is their own as traditional supporters of learners. Libraries are an obvious choice to deliver, for example, on the sixth key message form the 2000 Memorandum (bringing learning closer to home), as they already have established infrastructures in communities, and are highly trusted by the public (see for example, Usherwood, Wilson \& Bryson, 2005).

Three major trends can be identified which have had significant impact on how libraries perceive and articulate their role - and relevance - for the twenty-first century:

- Alignment of library goals with local, national and European policy agendas;

- Increasing formalisation of what libraries have always offered (in the form of learning support and opportunities);

- Partnership working with other educational providers.

In addition to these, there is also a move towards libraries as content providers, rather than as access facilitators; this is a small, but developing role, but seems set to grow in importance. The advent of ICT infrastructures in public libraries (such as the UK's People's Network) has, in many ways been a catalyst for much of the initiative. Not only has delivering ICT access and support been seen as a way to 
revitalise the image of libraries in the public mind, but it has also been seized eagerly by managers, library bodies and policy makers as a way to generate renewed interest (and investment) in libraries, and provide them with a role in the twenty-first century. In the UK, certainly, this trend is not without its critics, and much debate has been generated around the (possibly false) battle between ICT provision and traditional book provision. However, the role libraries will play in supporting lifelong learning agendas across Europe is set to stay.

At international level, this can be seen for example in the IFLA Public Library Manifesto and directives, which are also key for partner countries involved in the PuLLS project. The manifesto includes 12 key missions relating to information, literacy, education and culture, which should be at the core of public library services. These include: supporting both individual and self conducted education as well as formal education at all levels and facilitating the development of information and computer literacy skills (IFLA, 1994). The EBLIDA statement on the role of libraries in lifelong learning (EBLIDA, 2001), which supports the conclusions of the Lisbon European Council, suggests that:

Libraries therefore have a key role to play in underpinning learning in its broadest sense, both as a formal activity in an institution and informally within the community. Libraries, especially public libraries, can be a focal point for the local community, stimulating learning within the community at all levels. (EBLIDA, 2001)

Libraries, and library organisations from the partner countries in the PuLLS project have drawn on these statements to formulate their own positions, and to emphasise their commitment to supporting lifelong learning. In addition, many have adopted definitions which go beyond the rather narrower scope of EU and national government concerns with re-skilling, and training, to embrace wider concepts of the importance of learning. In the UK, the MLA (Museums, Libraries and Archives Council) has adopted the Campaign for Learning's definition for its Inspiring Learning for All initiative, supported by a toolkit to evaluate support of learning by these institutions. (http://www.mla.gov.uk/action/learnacc/00insplearn.asp). The commitment libraries have to supporting lifelong learning is well articulated by the Municipality of Århus' Library Policy, which stresses the personal dimension of learning for individuals, as well as supporting the more strategic aims articulated by the EU and national governments:

Lifelong learning is a key concept in a world, which is undergoing changes at a staggering pace. ... Lifelong learning relates to both the professional and the personal development of the individual. From a social point of view there is a need for a high level of education and strong innovation skills when competing with other countries.

libraries must support lifelong learning - the professional and the personal development alike. They must assist both students attending educational courses and anyone who independently wishes to become more educated. This could involve supporting public information activities, individual, personal interests or inspiration to learning.

(Århus Public Libraries, 2005: 9) 


\section{Public library activity in Europe}

This section provides a brief overview of some of the learning provision and activities undertaken across Europe, focusing on the partner countries involved in the PuLLS project.

\section{Access to learning materials}

Access to learning materials and support, both in the form of learning materials (in a variety of formats), and by offering information about learning opportunities is a wellestablished feature of public library provision. The Learning Exchange (the Oton Župančič Public Library, Ljubljana), for example, is a mediation point between learning providers and users, collecting learning requests and offers and establishing the link between request and offer. The origins of the service lie in the Adult Education Centre of Slovenia, which started as a pilot project in 1992. The first service was implemented in the library in Ljubljana, and there are now nine such services across Slovenia, in a national network. In the UK, Birmingham Central Library opened its Learning Centre in 2002, and houses PCs, a meeting room, a learndirect [footnote for explanation] room and a room for formal ICT sessions. There is also a self-study collection, ESOL collection, and Skills for Life collection. One of the aspects that differentiates this centre is the staffing: a team of staff (including some funded by learndirect) called Learner Support Officers, identify, select and acquire resources to support learning, and carry out tasks such as enrolling learndirect users (or directing learners to other materials where appropriate); they can advise and mentor learners, though they are not tutors.

\section{ICT facilities}

Provision of facilities to offer training in ICT skills is also a feature of European library provision, although here there are some interesting cultural differences in approach. In the UK, for example, the development of the People's Network [footnote], has reflected government policy on supporting training both in and via ICT skills. In Denmark and Finland, however, the emphasis for libraries has been less on fostering ICT skills, and more on providing training in information literacy skills. Projects such as 'The Barefoot Librarian' in Vejle providing information literacy skills for ethnic minorities, and the learning centre in Århus library, which provides individual training sessions for users, are typical of Danish library provision. Another feature common to both Denmark and Finland is the development of co-ordinated national services, such as the Danish Bibkurs, providing information retrieval skills via an e-learning package, and the PublicLibraries.fi portal operated by Finland's public libraries which has its own information retrieval channel that provides customers with extensive help in finding information from various sources on the Internet.

\section{Targeting communities}

Developing services for specific communities is also a growing trend of European library provision - Barcelona libraries for example provides materials and ICT to support self learning skills in Catalan (the official language of Catalonia), which aims to foster the integration of immigrant people. Tampere library in Finland also offers a library guide for immigrants, giving details of services in nine languages (http://www.tampere.fi/kirjasto/mamut/). The International Library in Frankfurt provides programmes for language learning and integration for ethnic minority communities, and Danish libraries provide FINFO (Information for Ethnic Minorities in Denmark), a web service which aims to: 
society. Access to information is considered a prerequisite to integration into society and to active participation in all spheres of social life.

(FINFO, 2007)

Part of this development involves taking services out to communities, and beyond the physical walls of the library itself is developing as a feature of public library provision; the Netti-Nysse (Internet Bus) in Finland is one such example.

The purpose of this mobile service is to encourage the residents of Tampere, Finland to start using computers and the Internet and give to them the initial guidance to be able to do that. Basic instruction is free of charge. Similar UK initiatives exist, such as LIAZe: Libraries and Information Access Zone (http://www.liaze.com/) a fully accessible bus service providing access to learning at community locations, coordinated to the needs of communities visited, which include travellers' sites, workplaces and old people's homes. They also offer wireless internet access and a short-term laptop loan scheme. Knowsley's ICT bus - Get IT on Board, launched in 2003, in partnership with community college and Community and Youth service offers a range of learning support.

\section{Partnership working}

Partnership working is becoming an increasing feature of library provision; whilst this has been part of the library landscape for some time, it is now becoming increasingly formalised. Germany has a well-established network of adult education centres and the PuLLS partner in Würzburg has developed open learning packages in conjunction with the Volkshochschule, including modules on finding information and learning (Information und Wissen), and learning and living (Lernen und Leben). This type of collaboration also exists in the Netherlands, with projects such as the agreement between the Dutch Volksuniversiteiten (Peoples universities), the Netherlands Public Library Association and two educational broadcasters. Launched in 2005, educational activities will be offered via television, radio, internet and libraries under one recognisable flag.

These developments all contribute to a changing library landscape, with the traditional model of a more 'passive' provision of access (for those motivated and skilled to take advantage of it) to a more active reaching out beyond established services and users, and an engagement with both user communities and wider policy agendas. Part of this shift involves moves towards the development of materials by libraries themselves, and the PuLLS project represents some of the activity in this area. Research in the UK suggests that this is much needed:

What is currently missing in nearly all public libraries is a well designed and extensive range of online courseware with content that is relevant to people's needs and interests as well as being fun and enjoyable. (Sommerland et al. 2004).

\section{PuLLS: aims}

The aims of the PuLLS project were to:

- Share skills, knowledge and expertise across the partner institutions;

- Develop a Europe-wide model for supporting adult lifelong learning;

- Provide learning opportunities for adult learners, particularly those at risk of exclusion from the 'information society'; 
- Develop a range of training materials to be delivered in open learning centres, and which could be shared with other libraries wishing to develop open learning facilities.

Part of the activities proposed were to specifically address the above point, in terms of creating content for adult learners, based on the kinds of skills libraries can offer (such as ICT skills, information-seeking etc. This is something of a departure for public libraries, whose traditional role has been to offer information about learning opportunities provided by others, and to offer supporting materials for individual study. During the project, librarians were to act as content developers (and, to varying degrees, as tutors); these are relatively under-developed activities in public libraries, and partners in the project had varying experiences of these roles to draw on.

\section{Methods}

The project ran from December 2004 to November 2006, and during that time, a number of key stages were identified and implemented.

\section{Developing a model}

The first activity was to share existing knowledge in order to identify what the elements of a successful model for open learning might be, and to develop a model which would then be adopted by those partners providing services to the public. Partners conducted desk research to provide information about policy initiatives and library activities in their own countries; these were then brought together and framed within wider the European context to produce an overview report [footnote]. From this, trends and differences in approach were identified, and elements extracted to inform a model for implementing open learning centres. Target groups were identified, and each library, using the model as a framework, devised its own plan for developing content and delivering services.

\section{Piloting the model/training courses}

From September 2005, the library partners worked on developing training materials, establishing open learning centres (or spaces) within their libraries, and delivering courses to their target audience(s). During this time, materials and experiences were shared via a number of mechanisms - the PuLLS website was a focal point for uploading content, partners shared experiences via webcams, and a physical meeting in Barcelona in April 2006 provided the opportunity to discuss progress, share experiences and materials, and monitor progress. An essential part of the project was sharing good practice; at the Barcelona meeting it was decided that, where possible, partners would try to adapt and use materials developed in other countries in their home institutions.

\section{Evaluation}

Two forms of evaluation were conducted; a common questionnaire was developed as part of the project for use with the users in each open learning centre, and an evaluation of the project using interviews with project partners was carried out by Trine Schreiber, of the Danish Royal School of Library and Information Science. 


\section{Results/outcomes}

The following section reports on the outcomes of the model and the courses offered to the public. The results incorporate finding from the evaluations - full reports on these (and all the materials developed) are available through the project website [footnote web address]

\section{A model for open learning centres}

The development of the model to inform the direction of how partners implemented open learning in their home countries was a useful way to distil information gathered as part of the desk research exercise. A number of elements were identified as desirable, and target groups for training also identified. Within the project overall, the target users were defined as those at risk of exclusion from the information society in some way (e.g. age, gender, ethnic origin, lack of ICT skills, lack of formal education), and specific user groups identified by each partner. The model included a range of other elements, all of which included aspects core to the project, and aspects deemed important to be decided at a local level. The elements of the model were:

- The training of users: different types of training (individual, group, e-learning etc.), and related issues such as the role of librarians - as trainers, teachers, guides?

- Staff issues: training of staff in new roles; focus on ICT, presentation and communication skills.

- Physical environment within the library: a flexible, open and accessible environment which should appeal to users.

- ICT: range of equipment to be used, including video conferencing, assistive technologies etc.

- Learning Materials: a range of multimedia courses, including those delivered over the web, and to include EU citizenship-related material.

- Evaluation of courses and trainers: use of questionnaires and focus groups to gain user feedback; questionnaires and interviews to gain views of library partners.

- Marketing: development of marketing plans very much devolved to local levels.

- Involvement of users in designing of courses and learning materials in open learning centres: this was not a key part of the PuLLS project, but it was agreed that it would be a useful issue to consider for future development.

Each partner library, then, developed and offered courses which contributed to the overall goals of PuLLS but which were considered most appropriate, or achievable, within their locality. Materials were shared both on the PuLLS website, and at partner meetings, and translated into the different languages. Some materials were developed in a number of languages from the outset (such as Barcelona's 'Finding the North' web tutorial, available in Spanish, Catalan, and English).

\section{Results}

\section{Introduction}

Many of the partner libraries built on existing provision or projects during the project, continuing work already started; others used the opportunity to set up new open learning centres (or spaces) and to release staff for training. Others were able to provide services for which they knew, or thought, there was a demand, though mostly 
this was based on impressions rather than any specific user needs evaluation with local communities. As one partner remarked:

We have not gone out in the area making heavy investigations about the needs of the people. We have some suppositions and we have looked at the experience of others. (Schreiber, 2006)

This had been highlighted in the model as an area of potential future development; however, the Würzburg partner did engage in some initial market research before embarking on the modules. A user needs evaluation was conducted, using focus group sessions with local people and this, combined with interviews with experts, assisted with the identification of suitable content. User feedback was additionally collected via questionnaire as the courses were rolled out.

\section{Target Users}

The project proposal identified adult users who had left school with only basic education, and those without ICT skills as key target groups. These were seen as groups likely to be at risk of exclusion from the 'information society' due to lack of technical or (information) literacy skills. The implementation of the model on a local level, however, meant that each partner library identified its own user group(s). Certain trends emerged in both what was offered to users - as might be expected, there was an emphasis on training in ICT skills - and in who was targeted (for example, a tendency to focus on providing opportunities for older people).

All libraries identified 'older users' as target groups, although there were different ages set, including 'adults over 45' and 'senior citizens'. Wherever the age limit was set, it was generally perceived that there was a demand for, in particular, ICT skills from older users, who also made up, in some areas, a large percentage of the population, and certainly of the existing library user population. The other target groups were women (in the Danish libraries) and the long-term unemployed (in Würzburg).

\section{Course content}

Five of the six partners developed courses in computer skills (the exception being Århus libraries. These courses focused on training users in the basics of computer equipment, and three partners also offered specific software training, for example using Microsoft Word. Sutton libraries for example, offered basic introduction to computer skills courses to the over 50 s. Courses lasted an hour, and numbers were restricted to six people (this later became eight), with one librarian to every two students. Five modules were offered: getting started; managing files; word processing; the internet; and email.

Searching for information, and using the internet were offered by all PuLLS partners, and there were some interesting variations in how this was approached. Helsinki, Ljubljana and Sutton integrated internet skills within their ICT skills classes, whereas Würzburg and Barcelona separated these courses out.

Despite none of the libraries using the term, many aspects of information literacy were developed during courses. Information literacy may be defined as follows:

Information Literacy is defined as the ability to know when there is a need for information, to be able to identify, locate, evaluate, and effectively use that information for the issue or problem at hand. (National Forum on Information Literacy, n.d.) 
With that definition in mind, it is clear that many PuLLS activities were addressing information literacy issues with their users. Århus libraries, for example, developed a specific module, How to Google, and also on training users in how to use specific websites (including: www.NetBorger.dk, a website offering citizens' information; www.aakb.dk, Århus public library website; and Fiction on the internet, using www.litteratursiden.dk). This approach reflects the existing tradition in Denmark for providing information literacy education (often on a one-to-one basis). The situation in the UK, for instance is somewhat different - since the implementation of the People's Network (and earlier), training in how to use a computer and very basic introductions to the internet and email have been commonplace.

Barcelona libraries developed a multimedia self-training course around searching for information on the web, entitled Troba el nord (Find the north), which was available in English, Catalan and Spanish. In addition to searching skills, this offered advice on interpreting results, thus also moving beyond the technical skills to further information literacy skills.

Appealing to new trends in technology was a successful aspect of a number of courses, with three libraries offering training in digital photography, and suggestions that future courses on, for example, how to use ipods, be introduced.

A strong emphasis on ICT and information-related skills is notable, suggesting that libraries are still happiest when offering training in areas where the existing staff expertise exists. However, Würzburg's provision was significantly different to other partners; an extensive range of courses was offered, including job applications , courses about reading and learning, and how to handle both work and private life conflicts and stress. The job-related courses were very popular in Germany, though interestingly, a similar offering by Århus did not attract any participants. This may have been due to marketing (one of Würzburg's target groups was unemployed people), or may be a reflection of the differing expectations of public libraries in different countries. Significant also in Würzburg was the extent of the joint working with a local institute of adult education - again, this reflects the culture and practice of German libraries.

\section{Course delivery}

The mode of delivery of course varied quite widely. Three libraries (Sutton, Helsinki, and Ljubljana) offered courses lasting several weeks, though the length of each session also differed - from one hour sessions in Sutton, to three hour sessions in Helsinki, whilst Ljubljana's ICT skills course consisted of three 'modules' each one lasting a day.

Of note here is the prevalence of offering training with low user-trainer ratios; whilst a few sessions were run as teaching sessions with up to 15 or 25 participants (e.g those delivered by the adult learning institute in Würzburg), the majority of courses enabled high levels of individual attention, ranging from 1:1 tuition to 1:4.

The target groups identified were quite consistent across the partner countries: older people (although that ranged from over $45 \mathrm{~s}$, to over $50 \mathrm{~s}$, to 'seniors'); the unemployed; and women [get details of which groups which partners targeted]. An important characteristic of the delivery of the training was the high teacher/trainerstudent ratio, with most courses running on a 1-8 basis as a maximum, and many providing 1-1 or 1-2 support. All partners carried out basic evaluation (via questionnaires) of the courses, and received very high ratings for the usefulness of 
courses. In Würzburg, for example, 93\% indicated they would participate in a similar course, and $100 \%$ that they would recommend courses to others.

All the partners intend to continue with their courses, and where possible to expand what they offer currently.

\section{Knowledge sharing between partners}

Although one of the aims of the project was to share knowledge - and possibly content - between the partners, it emerged that there were significant barriers to this. Firstly, the language barriers and need to translate material meant that partners tended to develop their own materials, rather than 'joint' or European content being created. For example, the Danish module, How to Google was deemed inappropriate for the level of users attracted to the courses in Sutton (the target group was the over 50s). Cultural differences also affected the type - and style - of materials offered. The starting point for each library was, naturally, what they already knew and did, or could do, within the scope of budgets and physical space. This tended towards building on existing strengths, and extending work already taking place. However, evaluations of the project by the partners indicate that knowledge sharing was valued by those staff taking part, and new ways of supporting adult learning were shared:

before going into the project we were not aware of the full potential for lifelong learning the libraries have; we saw training as a sporadic, individual activities, not as a strategic line to follow. Now, thanks to the PULLS experience, we are convinced that this is where our future lies. (quoted in Schreiber, 2006)

\section{Discussion: Implications for libraries}

A number of commonalities emerged in how the partners approached the project, and in what they offered users. Some interesting questions can be raised here about the popularity of courses offered - were the partner libraries successfully training users in what might be termed core library skills, or were they offering courses tailored to user demands? If libraries are to use the 'hook' of lifelong learning - via offering a wide range of training in consumer or technology-led skills - what are the impacts on staff and staff training, and what issues does this raise for what role libraries are - and should be - playing in terms of education? This can be seen as part of a wider debate about what the function of a public library is in the twenty-first century; part of the learning landscape or competing as an alternative leisure activity?

Offering a range of courses as part of a commitment to supporting learning of all kinds is set to become a feature of public library provision. What the PuLLS project has illustrated is the moves libraries are making in a number of directions, all of which can be seen as part of the formalisation of library roles referred to above, and party of what Trine Schreiber has described as a more aggressive mediation than previously (Schreiber, 2006). Libraries are moving away from passive modes of information provision towards actively seeking to engage and engage with their users - and crucially, attract new ones. This is demonstrated by the move from:

- Finding the information for the user to showing the user how to find information herself (i.e. supporting users in information literacy learning);

- Engaging in marketing of services as part of external communication with the (potential) user community more than previously; 
- Consciously testing new models and methods for reaching users and providing services.

What the PuLLS partners have shown, and have been committed to during the last two years, is the desire to make public libraries special places of learning that can attract users because of the strengths they have in meeting clients as individuals. Overall, the approach taken suggests that libraries are well suited to offer both ICT skills training and a range of information literacy support to groups of users who may have had little exposure to, for example, ICTs, and few opportunities for informal learning elsewhere. A certain shift has taken place in these libraries towards actually designing and delivering content, moving beyond the traditional role of providing access on a self-help basis. There are perhaps further developments which could be usefully pursued, such as actively engaging with users (and, importantly, current library non-users) in designing content and identifying areas of learning which draw on more than existing assumptions or 'hunches' that staff may have about user needs.

\section{Conclusions}

The PuLLS project has provided an enriching space for public librarians across Europe to share knowledge, and build their confidence in delivering content which supports adult learners, particularly those lacking ICT or information-related skills. The partners successfully delivered series of courses to users, which tapped into a demand for this kind of training in small groups allowing for high levels of individual attention. Most libraries were unable in fact to meet the demand for course, and the majority intend to keep running courses in the future. The project signals that libraries are building on traditional strengths in supporting learners, and in addition, beginning to move towards a more active service delivery, which targets services at groups of users, and also specifically develops content for those users. Staff also are gaining new skills and beginning to se a development of their role from passive facilitator to active provide, and in some cases, tutor.

1. The PULLS project consisted of eight partners, six of whom were public libraries implementing the model and delivering the courses. The University of Brighton provided research support and MK5060 Full Circle projects co-ordinated publicity materials and provided project management support.

\section{Bibliography}

Aarhus Public Libraries (2005) Library Policy 2006-2009 Available at: http://www.aakb.dk/graphics/portal/bibliotekerne/Bibliotekspolitik_2006-2009.pdf [accessed 27 January 2007)

Campaign for Learning. (n.d) About Us. Available at: http://www.campaign-forlearning.org.uk/aboutus/aboutus.htm [accessed 2 June 2005]

EBLIDA. (2001) The Role of Libraries in Lifelong Learning. Available at: http://www.eblida.org/position/LLL_Statement_June01.htm [accessed 16 January 2007] 
European Commission (2000) A Memorandum on Lifelong Learning. Available at: http://europa.eu.int/comm/education/policies/ll//life/memoen.pdf [accessed 20 January 2007]

European Commission (1995) Towards the Learning Society. Available at: http://europa.eu/documents/comm/white_papers/pdf/com95_590_en.pdf

European Commission (2003a) What is lifelong learning? Available at: http://ec.europa.eu/education/policies/III/life/what_islll_en.html [accessed 20 January 2007]

European Commission (2003b) Making a European Area of Lifelong Learning a Reality. Available at:

http://ec.europa.eu/education/policies/II//ife/index_en.html [accessed 20 January 2007]

European Commission (2006) It Is Never Too Late To Learn Available at: http://eur-lex.europa.eu/LexUriServ/site/en/com/2006/com2006_0614en01.pdf FINFO (2007) Information for Ethnic Minorities in Denmark. At: www.finfo.dk.

Finland (2003) Library strategy 2010. Helsinki: Ministry of Education. Available at: http://www.minedu.fi/OPM/Julkaisut/2003/kirjastostrategia_2010?lang=en [accessed 20 January 2007]

Germany (2004) Learning Regions - Providing Support for Networks. Berlin: Federal Ministry of Education. Available at:

http://deutschland.dasvonmorgen.de/pub/learning_regions_providing_supports_for_n etworks.pdf [accessed 20 January 2007]

IFLA. (1994) Public Library Manifesto. Available at:

http://www.ifla.org/VII/s8/unesco/eng.htm [accessed 16 January 2007]

Local Government Association (2002) Partnership in Action, London: LGA

Publications.

Ministerio de Educación (n.d.) Informe nacional sobre el debate acerca del aprendizaje permanente en España. Available at:

http://www.mec.es/educa/sistema-educativo/eadul/files/apren_permanente.pdf

[accessed 20 January 2007]

MLA (n.d.) A Quiet Revolution. London: MLA. Available at:

http://www.mla.gov.uk/webdav/harmonise?Page/@id=73\&Document/@id=26575\&Se ction[@stateld_eq_left_hand_root]/@id=4302\&Session/@id=D_eMKnd6xRowQksp5 4PgSK

MLA (2004) Inspiring Learning for All. Available at:

http://www.inspiringlearningforall.gov.uk/default.aspx?flash=true

[accessed 16 January 2007]

National Forum on Information Literacy, (n.d.) What is information literacy? Available at: http://www.infolit.org/ [accessed 16 January 2007]

NIACE. (n.d.) A Memorandum on Lifelong Learning. Available at:

http://www.niace.org.uk/Organisation/advocacy/memorandum/Default.htm [accessed 20 January 2007] 
Schreiber, T. (2006) The open learning centre in the public library: an evaluation of the experiences of the PULLS project. [unpublished project document - draft version available at www.pulls.dk]

Sommerland et al. (2004) Books and Bytes: new service paradigms for the $21^{\text {st }}$ century: an evaluation of the People's Network and ICT Training for Public Library Staff Programme. London: Big Lottery Fund

Tampere City Library (2006) Netti-Nysse is Internet Bus at:

http://www.tampere.fi/kirjasto/nettinysse/english.htm\# [accessed 16 January 2007]

Unesco (2005) International Adult Learners Week 2005. available at:

http://www.unesco.org/education/uie/InternationalALW/ [accessed 20 January 2007]

Usherwood, Wilson \& Bryson (2005) Perceptions of archives, libraries, and museums in modern Britain, Library \& Information Research, Vol.29, No. 93 pp. 50-57. 